\title{
Communication and Manpower Development: Implication for Local Government Administration in Nigeria
}

\author{
Goddey Wilson, Ph. D. \\ Department of Political Science, Faculty of the Social Sciences \\ Ignatius Ajuru University of Education, Port Harcourt. \\ Email-goddey.wilson@yahoo.com \\ Jide Ibietan, Ph.D. \\ Department of Public Administration \\ Nasarawa State University, Keffi. \\ Email : jidebetan@gmail.com
}

Doi:10.5901/ajis.2013.v2n2p135

\begin{abstract}
This paper is segmented into background, conceptual discourse: effective communication, and manpower development, findings and discussion, conclusion and recommendations. The main objective of this paper is to highlight the impact of effective communication and manpower development on local government administration in Nigeria. It is doubtful if the local governments can function and ultimately achieve their objectives without effective communication and developed manpower. Communication acts as a unifier of organizational activities, while manpower interprets and utilizes the communication to achieve the local government objectives. The study generated secondary data and used content analysis to analyse the data. The finding shows that effective communication and manpower development plans are vital tools to achieve functional local government administration in Nigeria. As a recommendation, it called on managers of the local government administration in Nigeria to be transparent and unambiguous in their communication process to achieve organizational effectiveness.
\end{abstract}

Keywords : Communication, Development, Effectiveness, Local Government, Manpower

\section{Background}

The desirability for effective communication and manpower development as a hallmark for local government administration is eminent in Nigeria. Communication appears to be the centre nerve of all activities in the organisation, hence, Cole (1996) explains that communication is a process of creating, transmitting, interpreting ideas, facts, opinion, and feelings between two or more persons in an organisation. No doubt, the activities of every organisation is centred to a large extend on communication, as advice and directive of both the subordinate and superior respectively are conveyed through communication. The manpower of the organisation use communication process as an instrument to achieve the organisational goal. The implication is that the success or otherwise of the organisation is dependent on the extent of the communication process, and the ability of the manpower to interpret same to achieve the objective of the organisation.

To that effect, it is the interest of this study to examine the role of communication and manpower development in achievement of effective local government administration in Nigeria. Secondary data were used for the study, while content analysis was used to interpret the data in other to achieve the objective of the study. Recommendations were made based on the findings on the strategies to achieve effective local government administration using communication and manpower development.

\section{Conceptual Discourse}

This section focuses on the concepts of communication, manpower development and local government. 


\subsection{Communication}

According to Weihrich, Cannice and Koontz (2008:385) communication is "the transfer of information from a sender to a receiver, with the information being understood by the receiver". The cardinal idea behind this definition is that communication is deemed successful when the receiver clearly understands the message. Communication is a process which underscores the role of the sender (encoding); the transmission; the receiver (decoding); feedback and the possible interplay of noise as barrier to effective communication.

Similarly, Cole (1996:207) and Eghe (2003:217) see communication as the process of creating, transmitting and interpreting ideas, facts, opinions and feelings between two or more persons. Communication therefore, implies a mutual exchange or interchange of ideas, facts, opinion and feelings between two or more persons. Stoner, Freeman and Gilbert (2000:546-547) see communication "as the process by which people attempt to share meanings through symbolic messages". Stoner et. al emphasise that communication is important to managers because it facilitates the management functions of planning, organizing, leading and controlling. This view tallies with those of Weihrich, Cannice and Koontz (2008) in the application of communication to all phases of management.

Robbins (2000:284) sees communication as the process of transmitting an idea or thought in such a way that the mental picture perceived by the receiver is exactly the same as that envisioned by the sender. When this happens, communication is said to be complete.

The systems theory as propounded by Katz and Kahn (1966) is of tremendous relevance and applicability to communication and the communication process. The reference to "input"; "conversion/processing"; "output" and "feedback mechanism" necessarily facilitate our understanding of communication, the process and problems/possible solutions. To that effect, Weihrich, Cannice and Koontz ( 2008:385) identified the purposes or functions of communication to an organization as thus:

- To establish and disseminate the goals of an enterprise

- To develop plans for their achievement

- To organize human and other resources in the most effective and efficient way

- To select, develop and appraise members of the organization

- To lead, direct, motivate and create a climate in which people want to contribute to the organization).

- To control performance.

\subsubsection{Types of Communication}

Scholars of Management and Organisational Behaviour tend to agree that communication can be classified into formal or official, informal or unofficial and lateral, diagonal or crosswise. Some organizational literature equates formal communication with vertical communication, while informal communication is synonymous with horizontal or lateral communication (Stoner et. al 2000).

\subsubsection{Formal Communication}

The operations of the formal communication system follow the classical hierarchical structure of an organization. Such a structure follows the line of authority, which takes the form of up and down movement of all formal communications.

Formal communication in its downward form transmits policies, instructions and such information as necessary for the determination of what must be done from the top management through middle management to the lowest levels of the organization. This downward form of communication reflects the traditional approach to administration by way of delegation of authority, and Luthans in Eghe (2003:212) argues that its purposes in an organization are as follows:

- To give specific task directives about job instructions.

- To give information about organizational procedures and practices

- To inform subordinates about their performance

- To provide ideological type of information to facilitate the indoctrination of goals.

Formal communication flows upward through the same lines of authority in the form of feedback from the lowest through the middle level to the final decision making level. Upward communication takes the form of proposals, reports, suggestions or recommendations from a subordinate to a supervisor or manager. This is referred to as non-directive communication. Although, this pattern is considered necessary to enable managers coordinate subordinate activities 
effectively, the under listed barriers render it ineffective: physical distance or inaccessibility; distortion at each level; attitude of the superior officers; inferiority complex on the part of subordinates and rigid adherence to work rules or tradition.

\subsubsection{Informal Communication}

The informal system provides necessary communication outside the established formal lines of authority. This is important to maintain organizational linkages and to fill in the gaps and omissions of the formal system. This type of communication is mostly limited to oral face-to-face. In most organisations in Nigeria, a lot of informal communication is done via rumours and gossips flowing through ethnic cliques and other sectional interests and associations. It has the advantage of speed over formal communication. Informal communication in organisations serves as a device for evaluating managers by their subordinates, since the formal channel does not provide for such actions. It is not unusual to see managers supplanting the formal structure of communication with the informal mode which in extreme cases could be very destructive in its consequence.

\subsection{Manpower Development}

It is customary for scholars and writers on organization to treat training, education and development of human resources or manpower either as synonyms or complements. Adequate care must be taken not to confuse the terms with one another. Cole (1996: 340) posits that education implies basic instruction in knowledge and skills designed to enable people improve their services, and it is personal and broad based. Training implies preparation for an occupation or for specific skills; it is narrower in conception than education or development, and it is job-oriented rather than personal. Development suggests a broader view of knowledge and skills acquisition than training. It is career-oriented and concerned with employee potential than with immediate skill. It thus sees employees as adaptable resources. Cole (1997:271) clarified the above arguments further by asserting that education will be taken to mean any long-term learning activity aimed at preparing individuals for a variety of roles in society as citizens, workers and members of family groups. Manpower development is directed towards future needs and it is concerned more with career growth than immediate performance. It is established that manpower development focuses on organization's future manpower requirements and employee's growth needs to strengthen the managerial competence grapple with the changing management environment. The common principle linking each of these three learning activities are acquisition of knowledge, understanding skills and attitudes which derives from the organizational manpower policy objectives, and dependent on synergy and partnership between the organization and educational, vocational, professional and research/development centres.

Ojo (1997:155) equates manpower development with human resource development (HRD) or human capital formation as the process of increasing the knowledge, skills and capacities of people for the purpose of achieving socioeconomic development of a country. Human capital formation is thus associated with investments in human beings and the development as creative and productive resources. It transcends expenditure on education and training to cover costs aimed at enhancing capabilities and increasing human productive efforts. Building on the works of Crawford (1984) and McFarland (1968), Ojo (1998: 212) examined the distinction between training and manpower development. To the scholar, training implies the ways in which specific knowledge and skills necessary to perform a specific job are taught and learnt, while development implies a parallel process in which people acquire more general abilities and information, but in ways that cannot always be tied directly to a particular task they perform. Training further implies the process through which organizations build the skills and abilities of non-managerial employees. Manpower development includes the process through which managers and executives acquire skills and competence in their present jobs, in addition to increasing capacity for future managerial tasks and uncertainties of different ramifications. This distinction between manpower training and development tend to create more difficulties and blurring of the terms as it purports that manpower training is for junior staff, while manpower development is for executives and managers, and it will be misleading to accept this with finality. However, it is important to underscore that training and development activities form both integral and important aspects of human resource management. The activities embedded in both concepts enable possible and necessary adjustments/enhancement of skills at every level of the organization.

A well-articulated manpower development policy, programme and activities will offer the under listed potentials to an organization: 
(a) Maintenance of adequate and suitable quantity and quality employees' skills.

(b) Development of knowledge/skill based workforce.

(c) Coordination of work experience and other forms of on-the-job development.

(d) Attaining improved job performance and productivity/product quality.

(e) Enhancing service delivery.

(f) Increasing employee motivation.

At the employee level, Cole, (1997) identified the under listed as benefits accrued to individual for participating in training and development progammes:-

(i) Improved job satisfaction

(ii) Added value of employee in the labour market.

(iii) Enhanced prospects of internal promotion (see for details).

The foregoing notwithstanding, Olowu and Adamolekun (2002: 99-100) building on Paul (1983) adduced the following as some of the most serious problems of manpower training and development in African countries:

- The tendency to construe training as a discrete event and not part of an overall programme of organizational improvement.

- Many trainees are selected on the basis of bureaucratic politics and patronage rather than on the basis of the greatest need.

- Competent trainers are rare, as training is itself a poorly developed profession.

- Training curricula and development models are usually based on borrowed models that are rarely updated

- Training and manpower development tend to be classroom-based, academic-style teaching dominates, and these raise serious questions of relevance.

- Training evaluations are usually limited to assessing happiness levels instead of impact on knowledge, attitudes, behaviour and job performance.

- Most training institutions are poorly financed/managed, and are usually heavily dependent on government.

\subsection{Local Government}

Adamolekun (2002:49-50) and Ezeani (2004:1-7) identified local government as a product of decentralized administration. The scholars proceeded to discuss the various forms of decentralization as "Deconcentration"; "Delegation"; and "Devolution". Adamolekun (2002:50) added fiscal decentralization as the transfer of responsibility for budgets and financial decisions from higher to lower levels of government". Decentralization constitutes the heart of relationship between central government and sub-national government units, it is mostly discussed under Intergovernmental Fiscal Relations. Among the types of decentralization mentioned above, the ideal type of local government is usually discussed under devolution which implies granting of powers and responsibilities over specific functions by the central government to local government, which in theory operates outside the control of the central government. Devolution connotes democratic decentralization in which the powers granted to local governments are backed by effective resources and a legal personality to operate. Deconcentration implies administrative or bureaucratic transfer of management responsibilities and resources to agents of the central government located outside the headquarters at one or more levels. These field offices of the central government are known as field administration. Delegation as an extensive form of decentralization amounts to granting authority and managerial responsibility for specific functions to organisations outside the central government structure. These organisations and agencies enjoy varying degrees of autonomy and according to Ezeani (2004:4) they include "special statutory bodies; public corporations; regional planning and Area Development Authorities".

Anele (2008:400) operationalised local government thus:

as a territorially demarcated non-sovereign community, members of which share common interest and feel attached to one another, have legal right and power to sue and could be sued, have governmental machinery for the day-to-day administration of the area, responsible for the development and transformation of its area of jurisdiction, and subordinate to the central government.

The scholar inferred from the definition that a local government has territory, population and government machinery. Implied in the definition are: locality principle; legal personality; subordinate status to the central government; 
and service delivery geared towards the development and transformation of its area of jurisdiction (locality). To what extent does the third tier of government in Nigeria perceive its roles as developmental and transformational? Local Government is "generally meant to be a system of territorial units with defined boundaries, legal identity, institutional structured powers and duties laid down in general and special statutes and a degree of financial and other autonomy" (Hills, 1974:23). This definition seem to underline the essence of successive local government reforms in Nigeria, and more importantly underscoring the Fourth Schedule of the 1999 Nigerian Constitution in which the functions and duties of local governments were clearly spelt out. However, do they have the type of autonomy (financially and in other areas) as envisioned by Hills (1974), especially against the backdrop of the role of state governments in supervising local government and through statutory allocations in the name of States-Local Governments Joint Accounts under which some state governments defraud their local governments.

Onyeoziri (2005:15-27) attempted to resolve the above puzzle, while alluding to the inconsistencies that characterise the logic of federal practice especially in Nigeria ,where each level/tier of government which is supposed to be coordinate and independent in its sphere become subordinated and this is contrary to the spirit of federalism as advocated by K. C. Wheare, who developed the original idea and treatise of federalism. Onyeoziri (2005) corroborated that federalism creates certain liabilities for the integrity of the state which derives from the tension that characterizes the inconsistencies in their logic - the logic of centralization and decentralization. The imperfections in state institutions also create some disability for federal practice. He therefore cautioned on the lacuna in discussing federalism without backing it with "the theory of state" (which is the infrastructure) onto which federalism is grafted. Thus, a mutual reinforcement of the two variables offers a reliable strategy in guaranteeing stable federal arrangements.

Local government in the communal sense means people's political instrument to participate in resource allocation, distribution and power acquisition. An in depth analysis of this definition covers the broad objectives of local government which are: political participation, efficient service delivery and resource mobilization. Political participation concerns the desire to involve local citizens in the management of their local affairs. Efficient service delivery which is closely knitted with the above factor is to ensure that the basic needs of local citizens are met as speedily and as efficiently as possible. Resource mobilization is to provide a framework within which local resources, both human and material are effectively mobilized (Adamolekun, 1983:7)

The National Guidelines for Reform of local government (1976:1) defines local governments as:

\begin{abstract}
Government at (the) local level exercised through representative councils established by law to exercise specific powers within defined areas. These powers should give the councils substantial control over local affairs as well as the staff and institutional and financial powers to initiate and direct the provision of services and to determine and implement projects so as to complement the activities of the state and federal governments in their areas and to ensure through active participation of the people and their traditional institutions that local initiatives and responses to local needs and conditions are maximized.
\end{abstract}

The above definition appears more comprehensive and clearer in content. It leaves no one in doubt as to the expected place and role of local government in governance and as a veritable agent of development and grassroots participation in the democratic process. In addition, it emphasizes the localism principle in the conduct of affairs and in service delivery at the third tier. Local government must be representative, autonomous to a reasonable degree; must be functional. It must also be technically and economically viable. It has to be representative in the sense that the policies made by it must reflect the wishes of the people; and to mobilize the local populace for self development. Reference to autonomy here is predicated on policy formulating and implementing ability together with independence on personnel matters of local government. It must be functional to carry out its aims and objectives. Economic viability means ability to generate financial resources internally while technical viability connotes the competence and expertise of its personnel in discharging duties and functions assigned to them. Scholars have argued however that local government's performance on internally generated revenue is poor due to the prevalence of poverty, tax evasion, corruption, fraud and outright diversion of funds among revenue officials and over dependence on statutory allocation (Duru, 2001:104-105; Ezeani, 2006:262-263). 


\section{Finding and Discusion}

\subsection{Effective Communication and Manpower Development: Implication for Local Government Administration in Nigeria.}

Our finding shows that socialization is an important aspect of communication in an organization, as it is used to achieve the organizational goals. Socialization or orientation is the process of ensuring the induction or introduction of selected personnel appropriately to the organizational policy and is the first step in training and manpower development cycle. Through this, employees learn the culture of the workplace, policies, responsibilities, expected behaviour and group relations. Communication facilitates the learning process, as the instructions, mission statements, goals and objectives of the organization including local governments are clearly expressed and appropriate channels are used in order to ensure that employees internalize the local government values.

Training and development enhances skills through refresher, on-the-job training and other manpower development programmes, which prepare employees for advancement and promotion. Training and development contribute to increasing employees' abilities for organizational effectiveness; and these become easy through appropriate communication aids, plans and strategies. Communication and manpower development in organizations, especially in the local government are virtually and mutually reinforcing. Effective communication is a vehicle to delivering qualitative training and manpower development programmes/initiatives in public sector organizations. Lectures, seminars and symposia are made easy through well focused communication strategies and instruments.

However, in a related discourse, Okoli (2000: 41-44) documented copiously the distorted role-relationships on the subject of manpower development and its planning in relation to the local government system in Nigeria. The scholar further submits that developing manpower plans and its responsibilities in the local government system are diffused and developed around many institutions and departments both within and outside the system. He corroborated that "more importantly, the relationships between and among these institutions and departments are not clear-cut and streamlined, as they vary from state to state, and from one local government to another".

Okoli (2000:41) identified a galaxy of discreet institutions having one role or the other to play as far as manpower planning and development is concerned in the local government. The lists of those institutions are the offices of the : Vice President, State Deputy Governor, Bureau for Local Government Affairs; Ministries of Local Government; Local Government Service Commission; Directors of Local Government Administration : and Heads of Personnel Unit. These units are charged with the responsibility of developing the local government manpower for effective productivity in the system.

The challenges accountable for the poor achievement of effective communication and manpower development in local government are lack of autonomy for local governments as third tier of governance; inadequacy of technical capacity; corruption/sundry official mismanagement; excessive bureaucratization/political interference and manipulation; leadership factor; discontentment or lack of job satisfaction among local government workers. From the foregoing discourse and analyses, the link between effective communication and manpower development in the local government system in Nigeria is clear.

\section{Recommendations and Conclusion}

It is clear from the foregoing that effective communication is the master key that unlocks issues and areas of organizational activity. This paper revealed the potent and patent use to which communication can be put to achieve the goals and objectives of local government system in Nigeria. It is incumbent on administrators of the local governments to identify effective strategies of making communication work in their organisations by adopting pro-active methods that enhances manpower development and organizational effectiveness.

In order to strengthen the communication situation in local government councils, this paper recommends the following:

- That managers should keep employees adequately informed on management philosophy and expectation in transparent and unambiguous manner.

- Communicate employees' performance promptly, clearly and with courtesy

- As a supplement to other management techniques, managers should practice supervision based on managing by wandering around (MBWA). Through this, issues requiring prompt action can be attended to.

- Effective managers should discover ways of combining the various types of communication that makes them tap into every segment of the organization in order to achieve results. 
- Managers should endeavour to practice Honest, Open, Transparent (HOT) communication.

- A very effective way of improving communication in organisations is to conduct communication audit which is a tool for analyzing communication related to many key managerial activities. It examines policies, networks and activities. It can really be a means to facilitating organizational goals/objectives.

The four major communication networks worthy of audit are as follows:

- The task related or regulative network consisting of policies, procedures, rules and superior-subordinate relationships.

- The innovative network comprising meetings, problems solving and suggestions for change.

- The integrative network made up of praise, rewards, promotion and issues or items that harmonise organisational goals with employees' personal needs and aspirations.

- The informative- instructive network including bulletin boards, company publications and the grapevine.

Role relationships among tiers and institutions of government should be clearly stated and devoid of ambiguity/unnecessary overlapping.

- This paper strongly advocates autonomy for local governments in such a way and manner that enhances their performance of constitutional and ancillary roles.

- The paper recommends a further review of the revenue allocation formula with improved revenues to local governments as the closest tier of government to the people (rural and urban).

- There is an urgent need for realistic political reforms that can decongest the federal government and whittle down the exclusive list in favour of the local governments.

- As an adjunct to the above, necessary constitutional reforms is canvassed as a matter of urgency to untie the local government councils from the apron strings of state governments, because the current practice of federalism in Nigeria detracts from the original idea.

- The Anti-graft war should be pursued with vigour and without selection. This has the potency of exposing corrupt public office holders and ensuring that justice is not only done, but seen to be upheld, thus serving as deterrent to potential offenders. This can assist in redressing the phenomena of resource mismanagement and corruption in the local government system.

\section{References}

Abada, I.M. (2007) "Local Government Autonomy in Nigeria: An Appraisal", in Journal of International Politics and Development Studies, UNN, Vol.3 No.1 (July/December), Page 244-261.

Adamolekun, L.. (1983) Public Administration: A Nigerian and Comparative Perspective. New York: Longman Inc.

Adamolekun, L.. (2002) "Decentralisation, Subnational Governments and Intergovernmental Relations", in Adamolekun, L. (ed.) Public Administration in Africa: Main Issues and Selected Country Studies. Ibadan: Spectrum Books Limited.

Adamolekun, L.. (2009a) "Nigeria Notes: Re-inventing Local Self-Governance". Vanguard (February 18) page 19.

Adamolekun, L.. (2009b) "Nigeria Notes: Governance and Development - An overview". Vanguard (February 25) Page 19.

Agi, S.P.I. (2002) "Local Government as third Tier of Government: Theoretical Problems", in Nigerian Journal of Public Administration and Local Government, UNN. Vol. 11, No.1, (January), Page 105-124.

Anele, K. A. (2008) "The Local Government System and Grassroots Transformation in a Conflict- free Environment", in International Journal of Communication, UNN. No. 8

Cole, G.A. (1997) Personnel Management (Fourth Edition). London: Letts Educational.

Cole, G.A. (1996) Management: Theory and Practice. (Fifth Edition). London: Letts Educational.

Duru, E. J.C. (2001a) "Essence of Local Government Reforms in Nigeria", in Duru, E.J.C; Ikejiani-Clark, M; and Mbat, D. O. (eds.) Contemporary Issues in Public Administration. Calabar/Benin: BAAJ International Company. Page 97 - 101.

Duru, E.J.C. (2001b) "Poor Revenue Base of Local Government: Causes and Cures", in Duru, E.J.C; Ikejiani-Clark, M; and Mbat, D.O. (eds.) Contemporary Issues in Public Administration. Calabar/Benin: BAAJ International Company.

Duru, N. (2009) "Why LGs should Explore Other Sources of Revenue." This Day (April 12)

Eghe, E. V. (2003) Rudiments of Public Administration. Kaduna: Joyce Graphic Printers \& Publishers Co.

Elekwa, N.N. (2004) "Responsibility and Ethics in Local Government Service", in Nigerian Journal of Public Administration and Local Government, UNN. Vol. XII, No. 1 (May).

Ezeani, E. O. (2004) Local Government Administration. Enugu: Zik -Chuks Nig.

Ezeani, E. O. (2006) Fundamentals of Public Administration. Enugu: Zik-Chuks Publishers.

Ezeani, E.O. (2009) "Strategies for Sustainable Wealth Creation by Local Government In Nigeria," in Nigerian Journal of Politics and Administration, UNN. Vol. 2, No.1 (January). Page 10-23.

Federal Republic of Nigeria (1976) National Guidelines for Reform of Local Government. Kaduna: Government Printers. 
Hills, D. M. (1974) Democratic Theory and Local Government. London: George Allen and Unwin.

Ibietan,J. (2010) "Local Government and the Localism Principle: A Review", in International Journal of Studies in the Humanities, UNN. Vol. 7, No. 8. Page 203-216.

Ikejiani- Clark, M.O. (2001) "Corruption in Local Government Administration: Challenges and Remedies," in Duru, E.J.C; Ikejiani-Clark, M. and Mbat, D.O (2001) Contemporary Issues in Public Administration. Calabar/Benin: BAAJ International Company. Page 122-137.

Maidoki, P.B. and Ibietan, J.I. (2010) "Human Factors in Organisations: Communication And Human Resource Management Interface," in Lapai International Journal of Management and Social Sciences, IBB University, Lapai. Vol 3, No 1 \& 2, 2010, Page 146-158.

Ngu, S. M. (1994) Personnel Management in Nigeria: Principles and Practice. Zaria: Gaskiya Corporation Limited.

Odoh, A. (2004) "Local Government and Democracy in Nigeria"; in Nigerian Journal of Public Administration and Local Government, UNN, Vol. XII, No .1 (May) page 175-188.

Odoh, A. (2004) "Understanding the Concept of Autonomy in Local Government Administration", in the Nigerian Journal of Public Affairs, ABU Zaria, Vol XVI, No. 1 (Dec), Page 44-55.

Ojo F. (1998) Personnel Management: Theories and Issues. Lagos: Panaf Publishing Inc.

Ojo, F. (1997) Human Resource Management: Theory and Practice. Lagos: Panaf Publishing Inc.

Olowu, D. and Adamolekun, L. (2002) "Human Resources Management," in amolekun, L. (ed.) Public Administration in Africa (Main Issues and Selected Country Studies). Ibadan: Spectrum Books Limited.

Onah, F. O. (2008) Human Resource Management. Second Edition. Enugu: John Jacob's Classic Publishers Ltd.

Onah, R.C. (2004) "Trends in State-Local Government Financial Relations and Local Government Administration in Nigeria", in Nigerian Journal of Public Administration and Local Government, UNN. Vol XII, No.1 (May) page 189-198.

Okoli, F. C. (2004) Theory and Practice of Public Organisations: A Book of Readings. Enugu: John Jacob's Classic Publishers Ltd.

Okoli, F. C. and Onah, F. O. (2002) Public Administration in Nigeria: Nature, Principles and Application. Enugu: John Jacob's Classic Publishers Ltd.

Okoli, F.C. (2000). "Developing Appropriate Manpower Plans in the Local Government System," in Onah, F.O. (2000) Strategic Manpower Planning and Development. Nsukka: Fulladu Publishing Company.

Onyeoziri, F. (2005) "Federalism and the Theory of State", in Onwudiwe, E. \& Suberu

R. T. (eds.) Nigerian Federalism in Crisis: Critical Perspectives and Practical Options. Ibadan: PEFS \& John Archers Publishers Ltd.

Robbins, S.P. (2000) Organizational Behavior (Ninth Edition). New Delhi: Prentice-Hall of India.

Shafritz, J. M. and Hyde, A. C. (1992) Classics of Public Administration. USA: Harcourt Brace College Publishers.

Stoner, J. A. F; Freeman, R. E \& Gilbert, D.R. (2000) Management (Sixth Edition). New Delhi: Prentice - Hall of India.

Udom, U. E. (2002) Adminisprudence- A Behavioural Approach to Managing Ourselves and Others. Ibadan: Spectrum Books Limited.

Weihrich, H; Cannice, M. V; and Koontz, H. (2008) Management: A Global and Entrepreneurial Perspective. Twelfth Edition. NewDelhi: Tata McGraw-Hill Publishing Company Limited.

Wright, H. N. (2001) Communication at work. USA: Regal Books.

Yalokwu, P. O. (2006) Fundamentals of Management. Second Edition. Lagos: African Centre for Management and Education. 